\title{
Pembelajaran Menggambar dengan Accelerated Drawing Technique (ADT) untuk Anak Usia Dini
}

\author{
Sevilia Sujarwo Indrias Putri, Trisakti \\ Program Pascasarjana/Pendidikan Seni Budaya, Fakultas Bahasa dan Seni Universitas Negeri Surabaya. \\ Jalan Lidah Wetan Surabaya, Indonesia \\ E-mail: sevilia.18003@mhs.unesa.ac.id
}

\begin{tabular}{ll}
\hline \hline ARTICLE INFO & ABSTRACT \\
\hline \hline Article history: & Penelitian ini memiliki tujuan untuk mengetahui pembelajaran menggambar \\
Received: $9-12-2019$ & Accelerated Drawing Technique (ADT) di sanggar Creativ Kids Kediri. \\
Revised: $16-12-2019$ & Metode penelitian ini menggunakan metode deskriptif. Subjek penelitian ini \\
Accepted: $23-12-2019$ & adalah siswa usia dini di sanggar Creativ Kids Kediri, sebanyak 36 siswa. \\
Keywords: & Pembelajaran menggambar Accelerated Drawing Technique (ADT) adalah \\
Pembelajaran, menggambar, & teknik cepat menggambar dengan menggunakan bidang yang ditarik garis \\
ADT, anak, usia dini & lurus atau lengkung sehingga menghasilkan gambar hewan yang diinginkan. \\
& Dari hasil penelitian yang didapat menunjukkan bahwa sebagian besar siswa \\
& di sanggar ini dapat menggambar dengan Accelerated Drawing Technique \\
& (ADT). Hal itu dapat dilihat dari hasil karya yang dibuat oleh siswa di \\
& sanggar. Hasil karya siswa sanggar yang mendapat kriteria baik 53\%, kriteria \\
& cukup 33\%, kriteria kurang 14\%. Pembelajaran mengambar Accelerated \\
& Drawing Technique (ADT) ini menanamkan karakter positif di antaranya \\
kreatif, disiplin, tanggung jawab, dan menghargai karya. Selain itu karya yang \\
dibuat memiliki keunikan tersendiri. Karya tulis ilmiah ini dapat bermanfaat \\
sebagai referensi di dunia pendidikan baik untuk siswa maupun guru di \\
sanggar maupun sekolah.
\end{tabular}

This study aims to determine the learning of Accelerated Drawing Technique (ADT) drawing at the Creativ Kids Kediri studio. This research method uses descriptive method. The subjects of this study were 36 young students at the Creativ Kids Kediri studio. Learning to draw Accelerated Drawing Technique (ADT) is a fast drawing technique using fields drawn in straight or curved lines to produce the desired animal drawing. From the research results obtained showed that most students in this studio can draw with Accelerated Drawing Technique (ADT). This can be seen from the work made by students in the studio. The work of studio students who get good criteria 53\%, enough criteria 33\%, less criteria 14\%. Learning to draw Accelerated Drawing Technique (ADT) instills positive characters including creative, disciplined, responsible, and appreciates the work. In addition, the work that is made has its own uniqueness. This scientific paper can be useful as a reference in the world of education for both students and teachers in the studio and school.

\section{PENDAHULUAN}

Menggambar memiliki peran yang tidak kalah penting dalam perkembangan anak usia dini, sebab pada anak usia dini, menggambar dan ketrampilan tangan merupakan salah kegiatan yang lebih banyak digemari. Kegiatan gambar anak penting untuk dikembangkan agar lebih menunjang kemampuan berfikirnya dan memancing kreativitas dengan kata akan memperlancar proses kreasi anak kelak dibidang apapun mereka berkiprah. Begitu mengagumkan ekspresi anak yang ia tuangkan melalui gambar. 
Anak usia dini adalah sebuah rentang usia yang sangat berharga bagi seseorang, dimana pada usia ini pertumbuhan dan perkembangan anak berkembang sangat pesat. Anak usia dini merupakan anak dengan rentan usia 2 sampai 6 tahun (Undang-Undang Nomor 20 Tahun 2003 tentang Sitem Pendidikan Nasional). Pada usia tersebut sering diistilahkan sebagai the golden age (usia emas), yaitu usia yang sangat berharga dibandingkan usia-usia selanjutnya karena anak lebih mudah menyerap stimulus yang dia dapat, selain itu pada usia ini kemampuan otak anak untuk menyerap informasi sangat tinggi (Susanto, 2017, p. 5). Memasuki usia tersebut anak mulai mengembangkan berbagai kemampuan dan keterampilan. Ketika anak mulai mengeksplorasi berbagai keterampilan yang dimilikinnya seperti belajar menggambar, setiap anak apabila diberi pensil, bolpoin, kapur, crayon, spidol, dan sebagainya secara naluriah mereka akan melakukan coret-coretan, entah itu coreng moreng tanpa arti atau sudah mulai ada arti dan kreativitas mereka akan dituangkan di berbagai media seperti tembok, tanah, meja, dan lain sebagainya. Pada umumnya ketika anak-anak sudah mulai aktif, maka mereka mulai suka corat-coret yang sederhana. Tabrani, (2005: 4), menegaskan coretan merupakan tahap awal kreativitas anak. Dengan bertambahnya usia, coretan akan mulai berkembang menjadi bentuk sebuah gambar yang lebih variatif dan jelas. Melalui gambar anak dapat mengekspresikan sesuatu yang ia rasakan, pikirkan, bahkan untuk menggambarkan pengalaman yang dialamainya.

Untuk selanjutnya anak akan berkembang secara bertahap sejalan dengan tingkat perkembangannya. Menurut Susanto (2017:73), kreativitas merupakan salah satu kemampuan yang dimiliki anak yang terpendam yang perlu untuk dikembangkan sejak anak usia dini. Setiap anak memiliki bakat kreativitas yang berbeda yang dapat dikembangkan sejak usia dini. Bakat kreativitas anak yang tidak dikembangkan sejak anak usia dini maka bakat yang dimiliki anak tersebut tidak berkembang secara maksimal. Setiap tahap kreativitas tidak selalu tegas, suatu tahap bisa lebih cepat, lebih lambat, sesuai kemampuan yang dimiliki anak. Peran orang dewasa dan guru bisa sangat penting apabila bisa mengembangkannya dan mengarahkan anak dalam proses berkreasi.

Selama ini, kurangnya kemampuan guru dan orang dewasa dalam memahami gambar anak bukan hanya mengakibatkan patahnya gairah menggambar anak, tetapi secara tidak langsung juga akan ikut menghambat perkembangan kreativitas anak. Untuk menemukan cara agar dapat mengembangkan dalam proses menggambar anak perlu dilakukannya eksperimen. Dari hasil penelitian di sanggar creativ kids Kediri dan hasil wawancara dengan pendiri sanggar yaitu Stevecta (30 Tahun), kiranya jelas bahwa tentang cara mengarahkan gambar anak, yaitu perlu menciptakan suasana yang menyenangkan agar anak lebih rileks dalam menuangkan kreativitasnya, teknik yang diajarkan juga dapat mempengaruhi hasil gambar anak. Berangkat dari hal tersebut perlu adanya suatu cara agar siswa terlibat aktif dalam pembelajaran. Salah satunya dengan memberikan metode pembelajaran yang bervariasi serta media pembelajaran yang dapat menyajikan aktivitas menyenangkan dan dinamis.

Untuk itu peneliti mencoba menerapkan teknik pembelajaran menggambar yang lebih menyenangkan dengan menggunakan Accelerated Drawing Technique (ADT). Accelerated Drawing Technique (ADT) adalah teknik cepat menggambar dengan menggunakan sebuah bidang yang kemudian dapat dirubah bentuk menjadi sebuah gambar tertentu sesuai dengan tema yang ditentukan. Pada model pembelajaran ini terdapat level dan tema dalam setiap tahapannya. Teknik pembelajaran ini didesain semenarik mungkin agar anak lebih mudah menerapkan sehingga dapat menciptakan suasana belajar yang menyenagkan. Pembelajaran dengan menerapkan teknik Accelerated Drawing Technique (ADT) diharapkan proses pembelajaran anak menjadi lebih aktif, dimana secara tidak sadar anak dapat belajar dengan menyenagkan dan proses pembelajaran tidak monoton. Sehingga diharapkan anak lebih mudah menyerap dan menerapkan teknik Accelerated Drawing Technique (ADT) dalam proses belajarnya.

Mengingat pentingnya penelitian yang terkait dengan pendidikan untuk anak usia dini, peneliti menemukan artikel terkait dengan hal tersebut yang diungkapkan oleh Wira Pertiwi (2018). Penelitian ini ditujukan untuk meningkatkan kreativitas anak. subjek penelitian ini adalah anak yang tergolong dalam anak usia dini yaitu di kelompok B PAUD. Pada penelitian ini menunjukkan bahwa $50 \%$ kemampuan belajar anak ditentukan dalam 4 tahun pertama, dan 30\%nya sebelum usianya mencapai 8 tahun. Oleh karena itu, perlu adanya sebuah usaha maksimal untuk merangsang tumbuh kembang anak usia dini secara optimal.

Hal senada juga diungkapkan oleh Mira Lestari (2019), dalam penelitiannya yang berjudul 
"hubungan pola asuh orang tua dengan kemandirian anak", menjelaskan bahwa memasuki usia 5-6 tahun anak mulai mengembangkan berbagai kemampuan dan keterampilan dalam mengurus diri. Mira menegaskan bahwa ketika anak mulai mengeskplorasi berbagai keterampilan yang dimilikinnya merupakan bentuk kemandirian anak usia dini.

Terkait dengan penelitian pembelajaran untuk anak usia dini, Vivi Sufiati dan Sofia Nur Afifah (2019), dalam penelitiannya yang berjudul "dini peran perencanaan pembelajaran untuk performance mengajar guru pendidikan anak usia dini”, menjelaskan bahwa upaya mengatasi kebosana anak dengan melakukan variasi pada pembelajaran. Variasi terdiri dari cara mengajar, metode/strategi, variasi media dan sumber belajar, serta pola interaksi. Guru pendidikan anak usia dini di Indonesia melayani peserta didik di bawah usia 6 tahun. Guru yang memiliki kompetensi pedagogik terlihat dari kemampuan guru memperlakukan anak sesuai karakteristik dan menggunakan metode maupun atrategi yang sesuai dengan karakteristik anak.

Ketiga aspek tentang pendidikan usia dini diatas akan menjadi rujukan dalam penelitian ini, selanjutnya memandu koridor permasalahan penelitian yang diungkapkan, yaitu bagaimana pembelajaran menggambar dengan Accelerated Drawing Technique (ADT) untuk anak usia dini. Dengan demikian, tujuan utama dari penelitian ini adalah untuk mendeskripsikan pembelajaran menggambar dengan Accelerated Drawing Technique (ADT) untuk anak usia dini ditinjau dari tiga aspek tersebut.

\section{METODE}

Penelitian ini menggunakan metode deskriptif. Mendeskripsikan serta menjelaskan keadaan yang sebenarnya maupun sebaliknya, seperti bentuk, aktivitas, karakteristik, perubahan, hubungan kesamaan, dan sebagainya merupakan metode penelitian deskriptif (Sukmadinata, 2013, p. 72). Pada penelitian ini mendeskripsikan dan menganalisis penerapan pembelajaran menggambar dengan teknik Accelerated Drawing Technique (ADT) kepada anak usia dini.

Subjek penelitian ini adalah anak usia dini yang belajar di sanggar seni Creativ Kids Kediri, siswa yang mengikuti kegiatan menggambar ini berjumlah 36 siswa. Dalam melakukan analisis data pembelajaran menggambar dengan Accelerated Drawing Technique (ADT) sebagai alternatif teknik cepat menggambar untuk anak usia dini, penulis bersumber dari data yang terkumpul. Data-data yang dikumpulkan berasal dari kegiatan mempraktekkan langsung menggambar Accelerated Drawing Technique (ADT) di tempat penelitian dan dari hasil dokumentasi. Kemudian penulis menganalisis hasil karya menggambar Accelerated Drawing Technique (ADT) yang dibuat oleh siswa sanggar Creativ Kids Kediri.

Dalam menganalisis data, penulis menggunakan instrumen penelitian. Instumen adalah hal yang paling penting dalam sebuah penelitian. Kualitas penelitian ditentukan oleh kualitas instrumen, dari instrument tersebut diperoleh data yang akan menjadi dasar temuan dan dijadikan sebagai kesimpulan (Arifudin, 2014, p.225). Pada instrumen ini berupa rubrik penilaian menggunakan skala deskriptif dan skor, untuk mengukur aspek yang akan dinilai penuli. Skala deskriptif ini didalamnya terdapat Baik, kategori Cukup, dan kategori Kurang (Kunandar, 2015).

\section{HASIL DAN PEMBAHASAN}

\section{Hasil}

Kegiatan pembelajaran di Sanggar Creativ Kids dilakukan 2 kali dalam satu minggu yaitu hari Jumat, dan Sabtu, selama 2 jam mulai pukul 14.30-16.30 WIB yang dibimbing langsung oleh Stevecta yaitu pembina sanggar sekaligus pemilik sanggar. Kegiatannya berlangsung di ruang kelas dengan luas $3 \times 3$ meter, yaitu ruang kelas khusus untuk kegiatan menggambar dengan dipisahkan antara Playgroup, TK, dan SD. Guru memulai kegiatan dengan mengajarkan satu persatu anak, guru mulai memulai kegiatan belajar dengan bercerita, anak dipancing untuk saling berkomunikasi agar untuk menciptakan suasana belajar yang menyenangkan, selanjutnya anak akan diberikan materi belajar dengan tema dan level masing-masing sesuai dengan usia anak. Anak akan diajarkan teknik menggambar dengan Accelerated Drawing Technique (ADT). Selama pembelajaran di dalam kelas anak akan terus didampingi dan dilatih dengan menerapkan teknik tersebut. Kegiatan belajar akan berlangsung selama 2 jam pelajaran. Apabila kegiatan belajar sudah selesai maka selanjutnya anak akan diberikan PR 
untuk mengulang atau menerapkan kembali materi yang sudah diberikan di sanggar. Hasilnya akan dikumpukan di pertemuan selanjutnya. Untuk alat dan bahan anak membawa peralatan dan bahan sendiri dari rumah, contohnya pencil, penghapus, buku gambar, dan lain sebagainya. Keistimewaan dari kegiatan belajar ini sebelum kegiatan belajar dimulai anak akan diberi cerita anak-anak untuk memancing respon agar tercipta suasana belajar yang menyenangkan. Antusias orangtua untuk menjadikan anaknya menonjol dan berprestasi serta mahir dalam menggambar dan mewarnai sangat tinggi, jadi fasilitas anak atau peralatan serta bahan untuk menggambar dan mewarnai sangat memadai. Berdasarkan hasil observasi partisipasif pada tahun 2019, kegiatan pembelajaran yang dilakukan di Sanggar Creativ Kids adalah yang pertama pengajar menyiapkan tempat pada waktu yang telah ditentukan oleh pengurus Sanggar, pada hari sabtu sore pukul 14.30 - 16.30 WIB, pengajar memakai pakaian rapi atau ada seragam khusus yang dipakai dan menyiapkan media pembelajaran yaitu kertas, pensil atau alat lainnya, namun biasanya anak-anak sudah menyiapkan peralatan sendiri dari rumah. Kemudian anak datang mengucapkan salam bersalaman dengan pengajar dan duduk menunggu pelajaran dimulai, tetapi ada beberapa anak binaan yang datang terlambat dari jadwal yang ditentukan, tetapi tidak ada hukuman untuk mereka yang terlambat, mereka tetap diperbolehkan untuk mengikuti pembelajaran, jumlah anak yang mengikuti pembelajaran biasanya ada 4 anak dalam sehari tergantung jadwal yang sudah ditentukan pada masing-masing anak. Kemudian bersama pengurus sanggar anak binaan yang telah datang mempersiapkan diri dengan duduk. Dalam setiap pembelajaran menggambar yang dilakukan Sanggar Creativ Kids, Stevecta sebagai pengurus Sanggar selalu mengikuti pembelajaran dan mendampingi anak-anak binaan belajar. Dalam proses pembelajaran di Sanggar Creativ Kids tidak menggunakan kursi, hanya menggunakan meja lipat untuk proses pembelajaran dan duduk bersama di lantai dengan pengajar, pada awal pertemuan tersebut guru membuka pembelajaran dengan memberikan cerita anak-anak.

Selanjutnya pengajar menyampaikan tujuan pembelajaran yang akan dilaksanakan, pada tahun 2019 ini pengajar menyampaikan tujuan pembelajaran menggambar pada anak-anak sanggar, kemudian pengajar memberikan sedikit penjelasan mengenai bahan, alat, teknik, dan menjelaskan gambar yang akan diberikan, pada awal pertemuan tersebut sanggar menjelaskan teknik menggambar yang bagus dengan menggunakan Accelerated Drawing Technique (ADT) yang sudah disiapkan, setelah memberikan contoh karya yang akan digambar, kemudian pengajar membagikan kertas yang masih kosong (belum ada full gambar) pada masing-masing anak. Lalu pengajar mengajarkan tentang teknik Accelerated Drawing Technique (ADT), dilanjutkan anak-anak mencontoh dan mempraktekkannya. Pada awal kegiatan pembelajaran ini, teknik mewarnai yang diajarkan pengajar disesuaikan dengan kemampuan anak-anak, dan karya dengan gambar yang simple diajarkan terlebih dahulu karena tingkat pengerjaanya yang mudah dibuat dan tidak terlalu sulit untuk mereka ikuti.

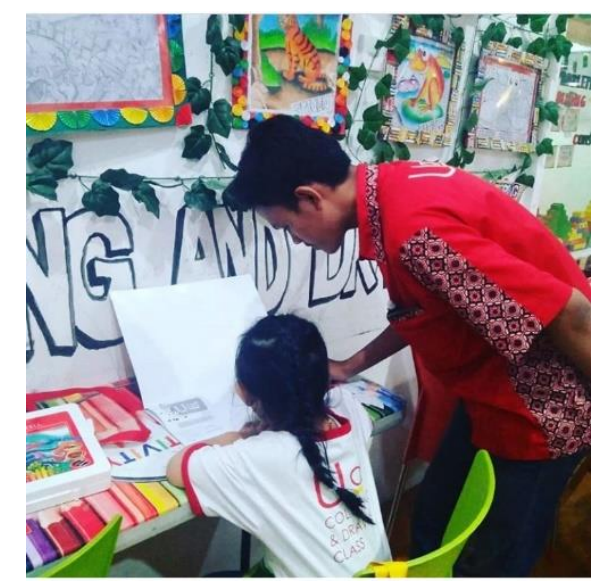

Gambar 1. Proses belajar mengajar di sanggar

Setelah pengajar mengajarkan teknik Accelerated Drawing Technique (ADT) pada anak, kemudian secara mandiri anak-anak binaan mengerjakan bahan gambar yang mereka dapat masing- 
masing. Kemudian pengajar membimbing anak-anak yang masih mengalami kesulitan untuk pengerjaan, tetapi ada juga satu dua anak yang langsung bisa ketika diajari dengan Accelerated Drawing Technique (ADT). Setelah selesai pembelajaran selama 2 jam pengajar menutup pembelajaran dan mempersilahkan anak-anak pulang, tetapi jika masih ada yang belum selesai mengerjakan maka mereka harus tetap berada di sanggar untuk melanjutkan gambar, untuk anak yang sudah selesai akan diberikan tugas yang sama dengan gambar sebelumnya untuk dibawa pulang dan dikerjakan di rumah. Setelah menutup pembelajaran anak-anak merapikan peralatan yang telah selesai digunakan. Dan dari hasil observasi partisipasif pada kegiatan pembelajaran menggambar sama seperti pada awal observasi partisipasif, hanya media pembelajaran dan teknik yang diajarkan lebih sulit dari sebelumnya yaitu membuat gambar yang lebih rumit, dan beberapa anak ada yang datang dan tidak datang sewaktu pembelajaran.

Hasil dari observasi tentang kegiatan pembelajaran tersebut diperkuat dengan hasil wawancara dengan owner yang menyatakan bahwa untuk pelaksanaan pembelajaran kegiatan biasanya pengajar menyampaikan kegiatan kemudian dicontoh dulu modelnya dan cara membuatnya, baru kemudian anak-anak mengikuti, dan hasil wawancara dengan owner mengenai kegiatan sebelumnya guru menyesuaikan teori menggambar sesuai dengan level anak. Dari hasil studi dokumentasi kegiatan pembelajaran menggambar untuk level yang paling rendah tidak jauh berbeda dengan pelaksanaan pembelajaran dengan level yang lebih unggul, hanya saja anak yang usianya diatas 6 tahun biasanya lebih dituntut untuk mandiri dalam proses pembelajaran setelah guru menjelaskan.

\section{Penerapan Teknik ADT di Sanggar}

Dalam metodologi pengajaran dapat diketahui bahwa ukuran baik dan buruknya suatu metode pengajaran terletak pada tujuan yang hendak dicapai. Metode pengajaran itu banyak jenisnya. Dalam proses pengajar atau membimbing guru dipersilahkan memilih salah satu atau beberapa metode yang menurut pendapatnya dapat dipakai secara efektif untuk mencapai tujuan pendidikan yang telah ditentukan ( Soehardjo, 1977:32).

Dari hasil penelitian yang dilakukan oleh penulis di Sanggar Creativ Kids Kediri yaitu menerapkan teknik pembelajaran Accelerated Drawing Technique (ADT). Teknik Accelerated Drawing Technique (ADT) adalah teknik menggambar dengan cara yang lebih simpel dan cepat. Kegiatan menjelaskan merupakan aktivitas mengajar yang tidak dapat dihindari oleh guru. Penjelasan diperlukan karena tidak terdapat dalam buku, sehingga guru harus menuturkan secara lisan. Ini berarti guru dituntut mampu menjelaskan. Untuk menyampaikan bahan pelajaran yang berkaitan dengan hubungan antar konsep, guru perlu menjelaskan secara runtut dan runut. Untuk menanamkan pengertian anak mengapa sesuatu itu terjadi, mengapa ini seperti ini, dan masih banyak lagi dalam berbagai peristiwa belajar mengajar yang menuntut guru untuk menjelaskan, (Marno, 2008:95).

Menurut Stevecta (owner sanggar), teknik pembelajaran Accelerated Drawing Technique (ADT) merupakan cara efektif untuk digunakan sebagai pembelajaran menggambar pada anak usia dini. Karena dengan teknik Accelerated Drawing Technique (ADT) anak diajarkan cara mudah menggambar dan terus mengingat langkah-langkah menggambar, anak menjadi tahu dan bisa berlatih menggambar kembali sewaktu di rumah dengan yang diajarkan sebelumnya di sanggar. Selain belajar di sanggar anak diberikan tugas rumah untuk menggambar atau melatih keterampilan tangan dan otak dengan cara menggambar kembali hasil gambar yang tadi dikerjakan di sanggar. Selain belajar di sanggar, anak diberikan tugas rumah utuk menggambar dan mewarnai atau melatih keterampilan tangan dan otak dengan cara menggambar kembali hasil gambar yang digambar di sanggar atau dengan tema yang sama. Anak menjadi berpikir dan mengasah serta membentuk ide-ide mereka untuk menentukan tema dan mengembangkan yang sudah diajarkan sewaktu di sanggar.

Selama proses belajar mengajar guru selalu menggunakan Accelerated Drawing Technique (ADT), setiap guru wajib menguasai teknik yang akan diterapkan kepada peserta sanggar karena setiap akan memulai pembelajaran menggambar guru selalu dituntut untuk menyiapkan bahan atau teori yang akan diajarkan, setiap anak mengerjakan level menggambar yang berbeda-beda sehingga guru dituntut untuk menguasai semua teknik pada setiap levelnya.

Jika ada perlombaan, kemampuan anak diasah terus untuk menggambar sesuai tema lomba. Anak diberikan materi yang sekiranya cocok atau gambar yang disenangi anak oleh pengajar dan berlatih menggambar terus dengan gradasi pewarnaan yang baik dan 
mengutamakan isi tema yang ditentukan oleh panitia lomba atau kompetisi lomba tersebut. Dengan teknik Accelerated Drawing Technique (ADT) yang diterapkan di Sanggar Creativ Kids Kediri ini mampu atau berhasil mencapai tujuan pembelajaran Sanggar yaitu seperti visi dan misi Sanggar "Menggali potensi anak dalam mempresentasikan karya secara sederhana, jelas dan mandiri, mengembangan kepercayaan diri, dan berpola disiplin". Dengan teknik pembelajaran yang diterapkan di sanggar tersebut adalah berhasil karena tujuan atau visi dan misi sanggar tercapai dengan keberhasilan yang dicapai yaitu anak didik Sanggar Creativ Kids selalu mendapat juara I, II, dan III umum bahkan tingkat Nasional.

\section{Hasil Karya Anak di Sanggar Lintang Art Kediri}

Berdasarkan pada hasil observasi, dokumentasi dan wawancara hasil karya anak di Sanggar Creativ Kids Kediri adalah sebagai berikut :
Nama : Betran
Kelas : TK-B
Tema : Binatang

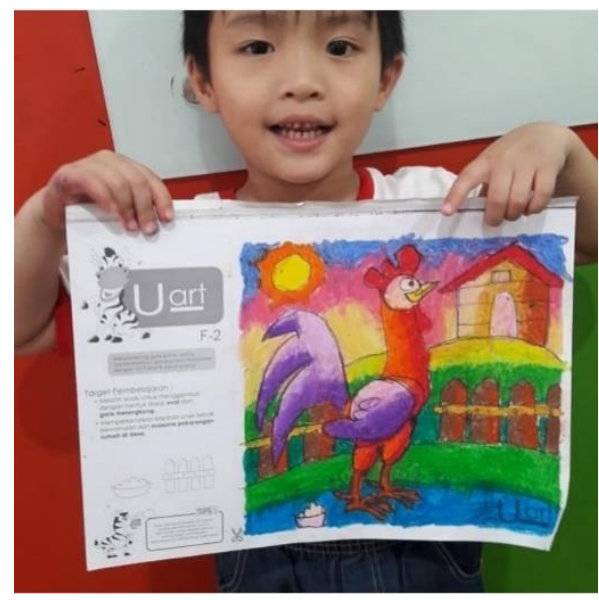

Gambar 2. Hasil belajar menggambar di sanggar

Tabel 1. Aspek Penilaian

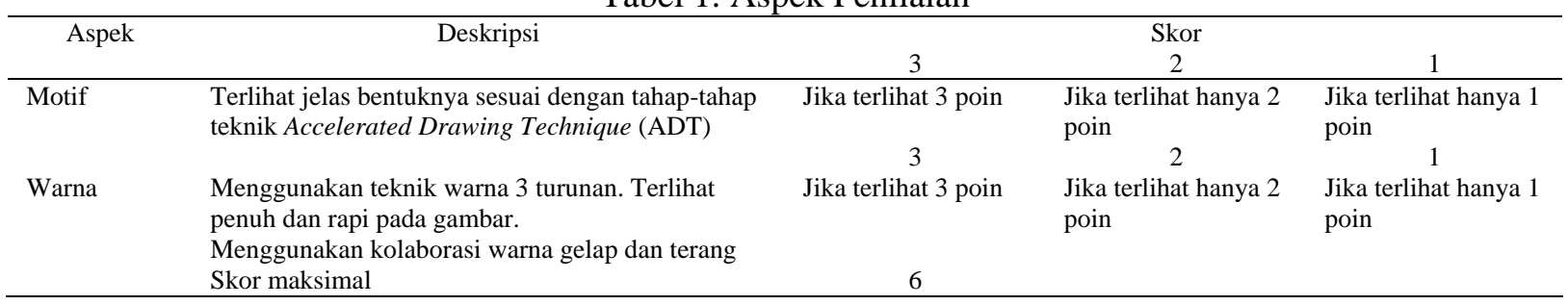

Selain menggunakan instrumen tersebut, penulis juga menggunakan pedoman penilaian yang dikutip dari Kunandar (2015). Pedoman penilaian ini untuk menentukan kriteria hasil karya menggambar anak dengan Accelerated Drawing Technique (ADT) yang diterapkan pada anak usia dini di sanggar Creativ Kids Kediri. Kriteria yang diberikan adalah Baik, Cukup dan Kurang. Skor yang karyanya mendapat skor maksimal 6, maka kriteria yang didapat adalah Baik. Sebaliknya apabila mendapat skor 2,66 ke bawah, maka kriteria yang didapat adalah kurang. Tabel 2 merupakan tabel pedoman penilaian:

Tebel 2. Pedoman Penilaian (Kunandar, 2015)

\begin{tabular}{ll}
\hline Rentang Skor & Kriteria \\
\hline $5,34-6$ & Baik \\
$2,66-5,34$ & Cukup \\
$2-2,66$ & Kurang \\
\hline
\end{tabular}


Dari hasil pembelajaran menggambar dengan Accelerated Drawing Technique (ADT) yang diterapkan pada siswa usia dini di sanggar Creativ Kids Kediri serta hasil analisis karya, didapatkan bahwa yang mendapat kriteria Baik berjumlah 20 anak, mendapat kriteria cukup berjumlah 11 orang, dan mendapat kriteria kurang sebanyak 5 anak. Apabila dikonverse ke dalam presentase yang mendapat kriteria baik 53\%, mendapat kriteria cukup 33\%, dan yang mendapat kriteria kurang $14 \%$.

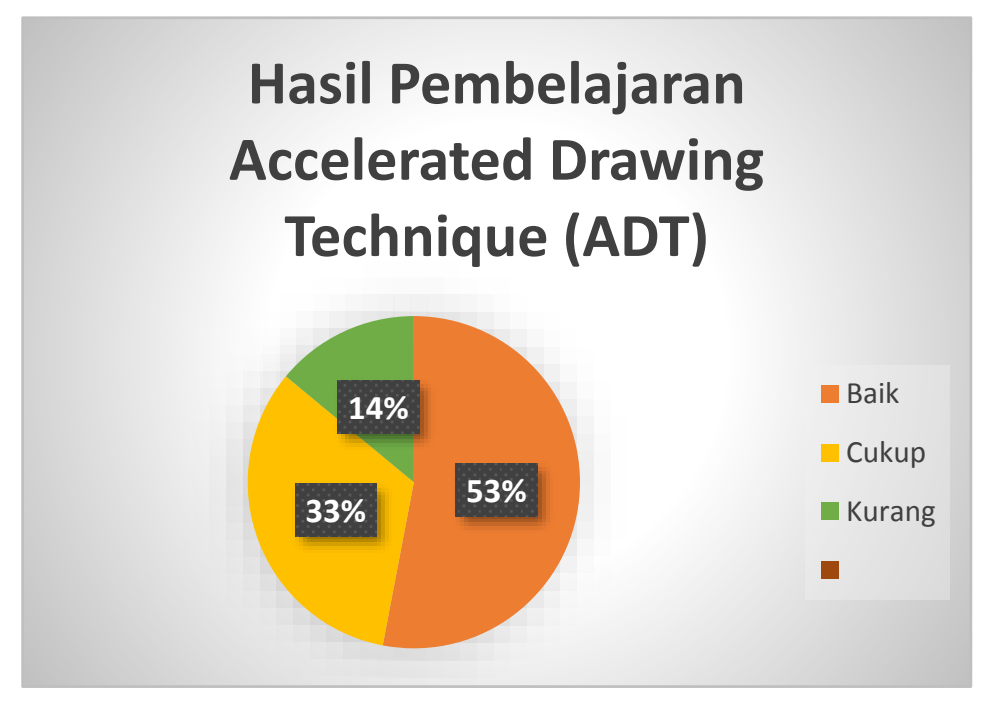

Gambar 3. Hasil pembelajaran Accelerated Drawing Technique (ADT)

Pembelajaran menggambar Accelerated Drawing Technique (ADT) yang diterapkan terhadap siswa di sanggar Creativ Kids Kediri, sebagian besar siswa dapat berkreasi dengan baik. Hal tersebut terlihat selama proses pembelajaran menggambar dari proses awal sampai akhir yang sesuai dan sampai karyanya selesai dibuat. Walaupun masih ada siswa yang membuat karya kurang rapi, namun presentasinya kecil. Pembelajaran menggambar Accelerated Drawing Technique (ADT) yang diterapkan pada siswa sanggar selain dapat berkreasi membuat gambar, secara tidak langsung juga membantu membentuk karakter yang positif. Karakter positif yang nampak pada praktek menggambar Accelerated Drawing Technique (ADT) adalah disiplin, kreativ, tanggung jawab, dan menghargai prestasi atau karya. Disiplin mengikuti pola pada teknik Accelerated Drawing Technique (ADT), kreativ dalam memunculkan ide-ide untuk menambah gambar serta mengkombinasi antara bentuk dan warna yang dipakai. Bertanggung jawab atas karya yang dibuat sampai selesai berdasarkan langkah-langkah menggambar. Untuk dapat menghasilkan gambar yang baik memerlukan proses yang lama, memerlukan kesabaran dalam membuatnya, sehingga siswa belajar menghargai karya yang dibuat baik dirinya sendiri maupun karya yang dibuat oleh temannya. Karakter positif ini diharapkan diaplikasikan siswa sanggar pada kehidupan sehari-hari di lingkungan keluarga, sanggar, dan dilingkungan masyarakat.

Pada hasil menggambar Accelerated Drawing Technique (ADT) ini terdapat keunikan. Keunikan tersebut adalah terlihat dari proses menggambarnya yang menggunakan bidang yang disusun atau ditarik garis lurus, lengkung sampai membentuk sebuah gambar yang diinginkan. Anak akan lebih semangat karena pada setiap level sudah disesuaikan dengan usia anak sehingga anak tidak merasa terlalu kesulitan. Keunikan inilah hanya dapat dicapai dengan menerapkan teknik Accelerated Drawing Technique (ADT).

\section{SIMPULAN}

Dari hasil pembelaran menggambar Accelerated Drawing Technique (ADT) yang diterapkan pada siswa di sanggar Creativ Kids Kediri dapat disimpulkan bahwa sebagian besar siswa di sanggar ini dapat menggambar dengan Accelerated Drawing Technique (ADT). Hal itu dapat dilihat dari hasil karya yang dibuat oleh siswa di sanggar. Hasil karya siswa sanggar yang mendapat kriteria baik 53\%, kriteria cukup 33\%, kriteria kurang 14\%. Setelah melakukan pembelajaran menggambar dengan Accelerated Drawing Technique (ADT) ini, diharapkan siswa 
sanggar dapat mengaplikasikannya setiap berkarya. Pembelajaran menggambar ini sebagai referensi siswa maupun guru yang mengajar di sanggar, dapat dikembangkan lagi dan dapat disesuaikan dengan baik. Pembelajaran menggambar Accelerated Drawing Technique (ADT) ini menanamkan karakter positif di antaranya kreatif, disiplin, tanggung jawab, dan menghargai karya. Selain itu karya yang dibuat memiliki keunikan tersendiri. Keunikan tersebut adalah terlihat dari proses menggambarnya yang menggunakan bidang yang disusun atau ditarik garis lurus, lengkung sampai membentuk sebuah gambar yang diinginkan.

Semoga karya tulis ilmiah ini bermanfaat sebagai referensi di dunia pendidikan baik untuk siswa maupun guru di sanggar maupun sekolah.

\section{UCAPAN TERIMA KASIH}

Terimakasih kepada sanggar Creativ Kids Kediri yang sudah memverikan ijin penelitian kepada peneliti. Ucapan terimakasih tidak lupa kami ucapkan kepada Pascasarjana Universitas Negeri Surabaya yang sudah memberikan stimulus untuk penelitian ini.

\section{DAFTAR PUSTAKA}

Guilford. 1986. An Organizational Approach to Childhood Depression. University of Minnesota Driven to Discover : (71-134).

Ira Rengganis. (2018). Analisis Gambar Karya Anak Sekolah Dasar. Jurnal Ilmu Pendidikan : Vol. 1, No. $1,(50-73)$.

Jalal. 2001. Translocation Involving The Immunoglobulin Heavy-Chain Locus Are Possible Early Genetic Events In Patients With Primary Systemic Amyloidosis. American Society Of Hematocology : Vol. 98, No. 98, (2266-2268).

Jamaris. (2006). Perkembangan dan Pengembangan Anak Usia Taman Kanak-Kanak. Jakarta : Grasindo.

Jung. (1964). La Riapertura Del Museo Di Storia Cina. Jornal Article : Vol. 8, No. 13, (29-36).

Karmas. (1976-2007). Optimizing Femoral Component Rotation in Total Knee Arthroplasty. Clinical Orthopaedics and Related Research : Vol. 392, No. 1, (38-45).

Kurniawan, Heru. (2016). Sekolah Kreatif Sekolah Kehidupan yang Menyenangkan untuk Anak. Yogyakarta : Ar-ruzz Media.

Lestari, M. (2019). Hubungan Pola Asuh Orang Tua Dengan Kemandirian Anak. Jurnal Pendidikan Anak.

Loita, Aini. (2017). Karakteristik Pola Gambar Anak Usia Dini .Jurnal Pendidikan : Vol. 1, No. 1, (114).

Majid, Abdul. (2014). Pembelajaran Tematik Terpadu. Bandung : Remaja Rosdakarya.

Munandar, U. (2004). Pengembangan Kreativitas Anak Berbakat. Jakarta : Rineka Cipta.

Pamadhi (2012). Pendidikan Anak Usia Prasekolah. Jakarta : Rineka Cipta Cet. II.

Pertiwi, W. (2018). Peningkatan Kreativitas Melalui Bermain Kreasi Berbasis Multimedia. Jurnal Pendidikan Anak

Prastowo. (2016). Experimental Study on a Standing Wave Thermoacoustic Prime Mover With Air Working Gas at Various Pressures. Journal of Physic : Vol. 710, No. 10, (1742-6596).

Rizki, Waridha Imaniar. (2017). Kajian Jurnal Bergambar Sebagai Media Komunikasi Anak Kepada Orang Dewasa di Sekitarnya. Jurnal Sosio Teknologi : Vol. 16, No. 3, (247-258).

Samples, JR. 1997. Mapping a Gene For Adult-Onset Primary Open-Angle Glaucoma to Chromosome 3q. American Journal of Human Genetics : Vol. 60, (296-304).

Sufiati, V., Afifah, S. (2019). Peran Perencanaan Pembelajaran Untuk Performance Mengajar Guru Anak Usia Dini. Jurnal Pendidikan Anak.

Sumantri. (2004). Leang Sakapao 1, a Second Dated Pleistocene site from South Sulawesi, Indonesia. Australian National University : Vol. 8, No. 00120, (111-128).

Susanto S, Sewan. Teks. (1980). Seni Kerajinan Batik Indonesia. Yogyakarta : Balai Penelitian Batik dan Kerajinan.

Susanto, Ahmad. (2017). Pendidikan Anak Usia Dini. Jakarta : Bumi Aksara. 
Sevilia Sujarwo Indrias Putri, Trisakti

Suyanto dan Djihad Hisyam. (2000). Refleksi dan Reformasi Pendidikan. Di Indonesia Memasuki Millenium III. Yogyakarta : Adicita Karya Nusantara.

Tabrani, P. (2006). Kreativitas dan Humanitas. Yogyakarta: Jalasutra.

Tabrani, P. (2014). Proses Kreasi Gambar Anak Proses Belajar. Jakarta : Erlangga. 